\title{
Gender, Work Schedules and Work/Family Regulation
}

The Gender and Work Technical Committee (TC) ${ }^{1}$ of the International Ergonomics Association (IEA) is responsible for this issue of the journal WORK. Since many of the authors come from the scholarly tradition of ergonomic analysis of work activity, we should explain that, in this context, the word "regulation" refers to the attempts made by workers and workers' groups to manage job requirements and constraints while meeting their own needs and respecting their own limits and abilities. Therefore the issue centers on work-family balancing strategies used in the workplace.

The TC, set up by IEA to provide a gender perspective in ergonomic analysis, has been particularly active in discussing themes like work schedule regulation, risk perception, work methods, and other themes at the intersection of gender and ergonomics: How can we understand the differences between men's and women's working conditions and their effects on health? How can we integrate gender-sensitive analysis into our intervention and research in ergonomics? How can we design working situations that take into account the biological and social differences between men and women? How to understand the various work activity and regulatory strategies of women and men in male-dominated, female-dominated and more mixed-sex workplaces? How does thinking about gender change our models and our methodologies for ergonomics research and intervention? This journal issue represents the results of some of these discussions.

The following explanations may be useful for those who are not familiar with French-language publications

\footnotetext{
${ }^{1}$ See http://www.iea.cc/browse.php?contID=gender_and_work for the thinking leading up to the establishment of this committee, its mandate, objectives and annual reports.
}

in ergonomics. ${ }^{2}$ Ergonomic analysis was developed to adapt work to human beings, implying re-examination of workplace design and work organization $[1,2]$. The field now called "ergonomic activity analysis" was first derived in France. Publications in English more often adopt a "human factors" approach, based in the natural sciences, relying more heavily on laboratory studies to produce norms and standards for tools, machines and worksites. Many of these studies are descended from scientific attempts to rationalize production and make it more efficient [3]. On the other hand, ergonomic activity analysis started by distinguishing between assigned tasks and actual work activity [4,5]. This induced ergonomists to abandon the laboratory for fieldwork and observation [6]. Because this group of ergonomists was rooted in practice, there was no question of studying work in the abstract: the purpose was to change it [7, 8]. The emerging field was rapidly populated by physicians, psychologists, engineers and physiologists and all struggled toward a holistic, interdisciplinary vision of work and the workplace that now includes exchanges and interactions with the human factors approach.

The work activity model evolved during the 1970 s to include functioning of the whole person at work borrowing theory from psychology on cognitive processes in simple and complex systems. The notion of work activity has remained central to the analysis, particularly targeting workers' strategies to deal with the

\footnotetext{
${ }^{2}$ Useful references for English speakers: Guerin F, Laville A, Daniellou F, Duraffourg J, Kerguelen A (2007) Understanding and Transforming Work. The Practice of Ergonomics. ANACT, Lyon. Messing K, Seifert AM, Vézina N, Balka E, Chatigny C (2005) Qualitative research using numbers: Analysis developed in France and used to transform work in North America. New Solutions: A Journal of Environmental and Occupational Health Policy 15(3), 245-260.
} 
variations in their environment due to interindividual differences, production fluctuations and changes in the social context. Workers are considered as the creators of their activity and their regulation strategies depend on their work situation; they develop at the same time as they regulate their own functioning and that of their work system [9]. It is this regulation of the activity that affects the workers' health and performance [10].

The integration of gender considerations into this stream of ergonomics research and practice has not been easy. Since, in theory, work should be adapted for all workers, gender-associated physical and social characteristics should automatically be included in ergonomic interventions, and many ergonomists resisted specific consideration of gender, age and other sociodemographic characteristics. However, the broad, holistic perspective of "activity ergonomics" eventually favored a consideration of social context and, eventually, research and practical interest in marginalized populations at work [11-13]. Intense discussions about specific groups such as ageing workers and women led to the realization that these population characteristics were not immutable biological attributes but rather challenges requiring a wider conception of social and physical adaptations by the workplace and at specific job sites $[12,14,15]$. As Teiger has pointed out [16], most early ergonomic studies concentrated on women's jobs without mentioning that fact. Women's work was in fact a prime subject for ergonomic analysis because the skills and activities required were often underrated $[5,17]$. And although most male and female biological characteristics and social roles overlap, the fact that many jobs are designed to fit with traditional male characteristics and roles can pose a problem for women $[18,19]$.

Some researchers have presented a critique of the dichotomy life at work/life outside work; they instead presented an activity system with " reciprocal control" of the two spheres [20]. The focus was on life outside work viewed as a context for an individual's regulatory strategies at work. However, ergonomists involved in the study of gender felt that strategies to regulate the interaction between home and workplace were an integral part of work activity, and therefore that work organization as it affected work-family balancing was a collective dimension of work and part of the purview of ergonomic intervention $[21,22]$. Ergonomic studies were called for, in order to render visible the strategies that link activity at home and in the workplace. The aim was to change the representation of these strategies and of the workers who employ them. As long as work-family balancing is viewed as a problem for the individual worker, or, worse, as a measure of the worker's degree of “organization”, the necessary transformations will not take place that give workers the leeway they need to handle work-family interactions, nor will employers take responsibility for developing skills and opportunities in this area.

The group of papers presented here shows that ergonomists can contribute to the study of work/family balancing in a gender perspective, by understanding how individuals and groups work out compromises so as to maintain their own and their families' physical, cognitive and emotional well-being in the face of the multiple demands and constraints of the workplace situation. This issue is innovative in that it concentrates on the actions taken by women and men in response to the increasing invasion of work schedules into family time and on solutions that have been developed. The authors have started to enlarge the scope of data collection in the workplace, considering the various interfaces involved; the papers here use a variety of methods, from the traditional ergonomics tools of observations and interviews to wider more quantitative studies.

Four articles deal with health and social services, traditional occupations for women. Estryn-Béhar and colleagues found that, for female and male physicians, work-family conflict was related to burnout; however, female physicians were twice as likely as males to say that their professional life was an obstacle to having children. Solutions were sought through team-building so as to diminish work-family conflict. Doniol-Shaw and Lada describe how female home care workers, faced with inadequate work organization that increases their work load, are unable to turn their backs on their patients, and so allow work time to overflow into family time. Solutions proposed involve increasing the leeway and control given to the workers to manage their time. For the group of women's shelter counsellors studied by Chatigny, the distribution of work schedules by seniority was a major problem for younger workers with families. The system was not only a major risk for workfamily conflict but also diminished younger workers' access to the more interesting tasks usually found during the day shift. The shelters' more senior workers had to think about renouncing the benefits of seniority in order to diminish turnover and guarantee survival of the shelters. The study by Barthe, Massing and Abbas concerns health care aides in a long-term care hospital, where schedules were to some degree irregular and unpredictable for a majority of personnel. The difficulty of the role of the schedule manager is augmented by the 
fact that work-family balancing, although required by the invasive scheduling, is not openly discussed. Two studies deal with work-family balancing in jobs that are non-traditional for women. Scheller describes the difficulties but also the advantages of bus driving as a profession for mothers of young children. Several mothers find that bus driving allows them to be home at the right time for their children, once they have found the right way to organize work and home life. Like the other authors, Scheller suggests that team work and collective discussions of work-family interactions would be beneficial. Caroly underlines the role of work organization in work-family interactions by comparing two work environments. In the primarily female health care profession of nursing, the work team was much more amenable to arrangements for women with young children than in the traditionally male profession of police work. Finally, Bernstein, a legal scholar, has analysed the strategies available in Québec, Canada, for lowpaid, low-status workers in the service sector. Since little of the research on work-family interactions has dealt with this type of worker, her article fills an important gap. Please note that three other papers on work-family interactions in the teaching profession will appear in a future issue of this journal.

It will become evident in reading the various papers that thinking about gender in connection with setting up work schedules requires us to reflect on collective work activity at work, how workers develop collaborative ways of regulating their environment. Collective activity is not present at the time of hiring; it is constructed over time, as a function of the team, and within the margins of what is allowed by the work organization [23]. It requires development of a working group and not just joint actions and can therefore be threatened by contemporary organizational strategies such as subcontracting and variable work schedules, where workers come and go as individuals [24]. Reconciling work with the world outside work is new even in gender studies in ergonomics and requires us to renew our models of work activity and rethink our analytical methods and our proposals for transforming work.

A very few of the papers here consider the different contexts of this regulation for men as well as women. In general, men are an under-studied lot in the nascent field of gender and ergonomics (although some work has been done, notably by Damien Cru [25], on men's strategies for managing risks). We hope that future research will deal with the different physical and social environments of women and men, as well as any gender differences in regulatory strategies. The notion of risk is critical to this consideration, since workers' strategies for health protection in the face of constraint depend on their perception of health risks and the relative weight given to health protection and maintenance of production.

We hope this collection will make a substantial contribution to ergonomics, to the study of work organization and to thinking about work-family balancing.

Guest Editors

Karen Messing

Researcher, CINBIOSE

Université du Québec à Montréal

CP8888, Succ. Centre-ville

Montréal, QC

Canada H3C 3P8

E-mail: messing.karen@uqam.ca

Sandrine Caroly

PACTE-CHRISTO

University of Grenoble (UPMF)

Domaine Universitaire BP47

38040 Grenoble Cedex 9

France

E-mail: Sandrine.Caroly@upmf-grenoble.fr

\section{References}

[1] A. Laville, Histoire et géographie de l'ergonomie française,

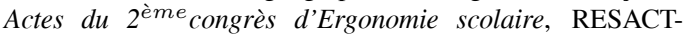
GRIESE Ed., 1988, pp. 5-17.

[2] A. Laville, Repères pour une histoire de l'ergonomie francophone. Congrès SELF-ACE, Montréal, 2001. Les transformations du travail, enjeux pour l'ergonomie. Vol.1 (2001), 1-6

[3] F.W. Taylor, The Principles of Scientific Management, New York: Harper Bros., 1911.

[4] A. Ombredane and J.M. Faverge, L'analyse du travail. Paris: PUF, 1955.

[5] C. Teiger and C. Bernier, Ergonomic analysis of work activity of data entry clerks in the computerized service sector can reveal unrecognized skills, Women Health 18(3) (1992), 6777.

[6] A. Wisner, Réflexions surl'ergonomie (1962-1995). Toulouse: Octares Éditions, 1995.

[7] A. Wisner, J. Marcelin and A. Briotet, A quel homme le travail doit-il être adapté? Paris: Collection du Laboratoire de Physiologie du travail-Ergonomie du Conservatoire National des Arts et Métiers, rapport n 22. 1971 (rééd. en 1976).

[8] F. Guerin, A. Laville, F. Daniellou, J. Duraffourg and A. Kerguelen, Understanding and Transforming Work. The Practice of Ergonomics. ANACT, Lyon. 2007.

[9] P. Falzon, Ergonomie, Paris: PUF. 2004.

[10] J. Leplat, L'analyse psychologique de l'activité en ergonomie. Aperçu sur son évolution, ses modèles et ses méthodes, Toulouse: Octarès Editions, 2000. 
[11] E. Cloutier, H. David, J. Prévost and C. Teiger, Importance of experience for older home care workers in facing up to the constraints of work, Exp Aging Res 25(4) (Oct-Dec 1999), $405-410$.

[12] S. Gravel, J.-M. Brodeur, F. Champagne et al., Critères pour apprécier

les difficultés d'accès à l'indemnisation des travailleurs immigrants victimes de lésions professionnelles, PISTES $\mathbf{8}(2)$ (2006). http://www.pistes.uqam.ca/v8n2/articles/v8n2a6.htm accessed May 28, 2011.

[13] K. Messing, La pertinence de tenir compte du sexe des "opérateurs" dans les études ergonomiques: Bilan de recherches, Perspectives interdisciplinaires sur le travail et la santé PISTES 1999 http://www.pistes.uqam.ca/v1n1/articles/ v1n1a5.htm.

[14] S. Premji, K. Messing and K. Lippel, Broken English, broken bones? Mechanisms linking language proficiency and occupational health in a Montreal garment factory, International Journal of Health Services 38(1) (2008), 1-19.

[15] K. Messing, K. Lippel, D. Demers and D. Mergler, Equality and difference in the workplace: Physical job demands, occupational illnesses, and sex differences, National Women's Studies Association Journal 12(3) (2000), 21-49.

[16] C. Teiger, "Les femmes aussi ont un cerveau!". Le travail des femmes en ergonomie : réflexions sur quelques paradoxes, Travailler 15 (2005), 71-130.

[17] N. Vezina, D. Tierney and K. Messing, When is light work heavy? Components of the physical workload of sewing machine operators working at piecework rates, Applied Ergonomics 23(4) (1992), 268-276.
[18] K. Messing, A.M. Seifert and V. Couture, Les femmes dans les métiers non-traditionnels : le général, le particulier et l'ergonomie, Travailler 15 (2005), 131-147.

[19] L. Scheller, How dangerous is the liaison between professional work and family work? The case of women bus drivers, Work 41(3) (2012)

[20] C. Gadbois, L'analyse des emprises réciproques de la vie de travail et de la vie hors travail, Bulletin du CERP 23(2) (1975), 117-151.

[21] K. Messing, L'application d'une méthodologie ergonomique à la conciliation des responsabilités professionnelles et familiales. in ed. Christine Corbeil et Francine Descarries, Ré/conciliation Famille-Travail: Les Enjeux de la Recherche, Montréal: UQAM. Cahiers de recherche féministes, 1995, pp. 51-72.

[22] J. Prévost and K. Messing, Stratégies de conciliation d'un horaire de travail variable avec des responsabilités familiales, Le Travail Humain 64 (2001), 119-143.

[23] S. Caroly, Activité collective et réélaboration des règles: des enjeux pour la santé au travail, document d'habilitation à diriger des recherches en ergonomie, Université de Bordeaux 2, 2010. http://tel.archives-ouvertes.fr/tel-00464801/fr/.

[24] A.M. Seifert, K. Messing, C. Chatigny and J. Riel, Precarious employment conditions affect work content in education and social work: Results of work analyses, International Journal of Law and Psychiatry 30(4-5) (2007), 299-310.

[25] D. Cru and C. Dejours, Savoir-faire de prudence dans les métiers du bâtiment, Cahiers Médicaux-Sociaux 27 (1983), 239-247. 